
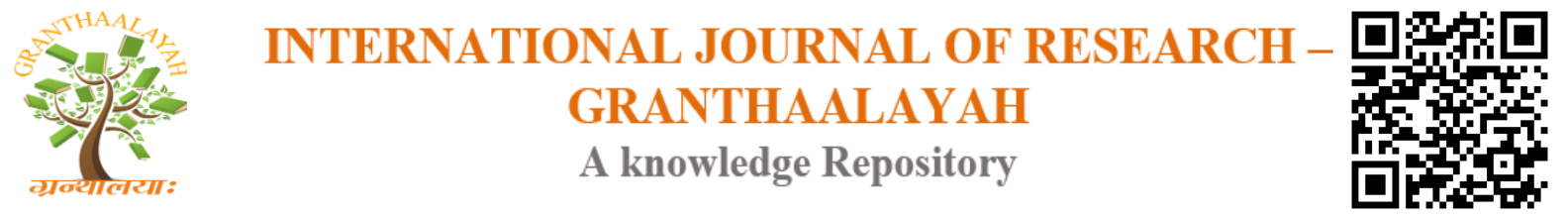

Science

\title{
SIMULATION STUDY OF PARABOLIC TROUGH SOLAR POWER PLANTS IN BRAZIL
}

\author{
Antonio Marcos de Oliveira Siqueira ${ }^{1}$, Gabi Antoine Altabash ${ }^{2}$, Rayan Fadi Barhouche ${ }^{3}$, \\ Gabriel Siqueira Silva ${ }^{4}$, Fábio Gonçalves Villela 5 \\ ${ }^{1}$ Universidade Federal de Viçosa, Programa de Pós-Graduação em Engenharia Química \\ (PPGENQ), Viçosa, Minas Gerais, Brazil \\ ${ }^{2}$ American University of Beirut, Beirut, Lebanon \\ ${ }^{3}$ American University of Beirut, Beirut, Lebanon \\ ${ }^{4}$ Universidade Federal de Viçosa, Florestal/MG, Brazil \\ ${ }^{5}$ Universidade Federal de Viçosa, Viçosa/MG, Brazil
}

\begin{abstract}
Various data reveals the potential of concentrated solar technologies for the electricity production. With global growing energy demand and green-house gas emission, concentrating solar power is considered as one of the promising options and has invited wide attention. In this work, a model for a $30 \mathrm{MW}$ parabolic trough solar power plant system was developed for 31 different locations in Brazil, using TRNSYS simulation software, and TESS and STEC libraries. The power system consists of a parabolic trough solar collector loop connected to a power block by a series of heat exchangers. The solar collector loop consists of a field of parabolic trough collectors, stratified thermal storage tank, pump and heat exchangers to drive the power block and uses Therminol VP1 as heat transfer fluid. The results show that the cities of Recife (PE), Fortaleza (CE), Belterra (PA), Salvador (BA) and Petrolina (PE) stand out for their high monthly values of direct normal irradiation and, resulting the highest production of energy by the same configuration of Solar Central Power Plant.
\end{abstract}

Keywords: Solar Energy; Solar Thermal; Parabolic Trough Collector; Concentrating Solar Power (CSP).

Cite This Article: Antonio Marcos de Oliveira Siqueira, Gabi Antoine Altabash, Rayan Fadi Barhouche, Gabriel Siqueira Silva, and Fábio Gonçalves Villela. (2019). "SIMULATION STUDY OF PARABOLIC TROUGH SOLAR POWER PLANTS IN BRAZIL." International Journal of Research - Granthaalayah, 7(8), 17-28. https://doi.org/10.29121/granthaalayah.v7.i8.2019.634.

\section{Introduction}

Solar energy has many benefits including environmental protection, economic growth, job creation, and diversity of fuel supply. Solar energy technologies can be deployed rapidly, and have the potential for global technology transfer and innovation. Various data reveals the potential of 
concentrated solar technologies for the electricity production. With global growing energy demand and green-house gas emission, concentrating solar power is considered as one of the promising options and has invited wide attention. Brazil is a developing country with an increasing energy demand. Solar resources and large areas are widely available in some parts of the country. Concentrating Solar Power (CSP) plants operate on Direct Normal Irradiance (DNI).

With all the revolution in technology that is occurring every single second in our life, the use of more power for manufacturers became an obsession. Since production of energy is highly dependent on non-renewable energy sources such as fossil fuel, the search for other renewable sources has been under research and implementation since the end of the last century. For instance, the use of solar power to produce energy has been a target.

Through the years of developing solar power, different types of solar collectors have been produced to efficiently collect the sun radiations and produce more power. Some types of solar collectors are Evacuated tube solar thermal systems, Flat plate solar thermal systems, Thermodynamic solar panels, Compound Parabolic Concentrator (CPC) solar collectors, Parabolic Trough Collectors and many other types of solar thermal collectors. In this work the study will be focused on the Compound Parabolic Concentrator (CPC) solar collectors and the Parabolic Trough Collectors.

As a part of this work, a study has been made to implement a solar thermal power plant in different places in Brazil. A simulation for this work was made in this report using TRNSYS simulation program. The simulation uses the Parabolic Trough solar collector along with other components to produce power. The simulation was built using built in components from TRNSYS, with TESS and STEC libraries. The purpose of this work is to compare between the different Parabolic Trough Solar Power Plants in Brazil and predict the best place to install it.

\section{Previous Modeling and Simulation Studies}

Lippke [1] produced a detailed thermodynamic simulation model of the Parabolic Trough Solar Power Plants, using EES simulation software. The objective of the Lippke model was to simulate system behavior during part-load conditions. In this model, design state points from the technical plant description was used to back-calculate turbine state efficiencies and overall conductance values for all heat exchangers in the cycle. The model was validated against hourly plant data for both a clear summer day and a clear winter day (the year from which data was taken for validation is not specified). Lippke [1] compared various conditions of receiver tubes, fraction of mirrors lost due to breakage and measured reflectivity based on measurement results of a LS-2 Parabolic Trough Collector. The objective of this study was to model system behavior during part-load conditions. Good agreement between the power plant model predictions and measured data was achieved.

Jones et al. [2] developed in the TRNSYS software a detailed performance model of the $30 \mathrm{MW}$ SEGS VI parabolic trough plant, using the Solar Thermal Electric Component model library. The developed model provides detailed state-property predictions for both the solar field and the conventional power cycle at the SEGS VI plant during solar-only operation. There was good 
agreement, usually less than $10 \%$ difference, between the model predictions and plant data, and the transient effects such as startup, shutdown, and cloud response were satisfactory modeled.

Stuetzle [3] has been established a nonlinear model of the $30 \mathrm{MW}$ parabolic trough plant. The model consists of a dynamic model for the collector field and a steady-state model for the power plant. The collector field model was presented as coupled partial differential equations for energy. The performance of this model was evaluated trough a comparison between predicted and measured data. The results of the developed model agree with the measurement.

The heat transfer analysis of parabolic trough solar collector can start with unidimensional model at radius direction and then expand de concepts along the flow direction in a bidimensional model [4]. This unidimensional assumes that all temperatures, heat fluxes and detailed thermodynamic properties are uniform around the HCE circumference unless indicated different. This model was validated with several sets of performance data from the collectors and used to study the influence of difference absorber tube materials, annulus gases, selective surface coatings, and glass envelope diameters.

A model for simulation and performance evaluation of Parabolic Trough Solar Power Plants was developed using the TRNSYS simulation program by Patnode [5]. In this case, the Rankine power cycle was separately modeled with a simultaneous equation solving software (EES). The steadystate power cycle performance was regressed in terms of the heat transfer fluid temperature, heat transfer fluid mass flow rate, and condensing pressure, and implemented in TRNSYS. Both the solar field and power cycle models were validated with measured temperature and flow rate data from the SEGS VI plant.

The work of $\mathrm{Qu}[6]$ has developed suggestions and methods for the effective design and evaluation of Parabolic Trough Solar Power Plants. Qu [6] also optimized the design and operation of solar absorption cooling and heating systems, so that the system is able to reduce building energy consumption, and achieve environmental benefits in the operation of buildings by the use of solar energy.

A thermal design and simulation of the parabolic through solar collector has been developed with Matlab software [7-8]. The developed software takes some primary data into account such as collector rim angle, optical properties of the mirror like its thickness and reflectance coefficient, errors in construction and installation of the collector, temperature of inlet and outlet of oil from the collector, temperature rise in the collector, date and day of design and its relevant data such as cloud factor, wind speed and ambient temperature, geographical location of the design point and length of the collector [8]. In this paper, it has been studied the most practical method of producing $500 \mathrm{~kW}$, utilizing a hybrid system.

A comprehensive numerical simulation of a parabolic trough solar power plant was proposed by Padilha [9]. This methodology was used to obtain optimum parameters and conditions such as: solar field size, operating conditions, parasitic losses, initial investment and LCOE. The new methodology was implemented for a $50 \mathrm{MW}$ parabolic trough solar power plant for Tampa and Daggett. The results obtained by Padilha [9] were compared to another physical model (System Advisor Model, SAM) and a good agreement was achieved. 
Desai et al. [10] developed a simulation of a grid-connected solar thermal power plant, with a gross capacity of $1 \mathrm{MWe}$ in India. In this plant there was realized the integration of two different solar fields (parabolic trough collectors and linear Fresnel reflectors), without a fossil fuel backup.

Uçkn [11] developed a mathematical model of direct steam generation using parabolic trough collectors. The model's predictions were compared with previously published data and good agreement was found. A parametric study for direct steam generation in parabolic trough collectors was presented for different inlet temperature and pressures, and solar resources. The direct steam generation mathematical model was integrated into a TRNSYS model of a complete solar thermal power plant. The results were compared with previously published and acceptable results are found.

The operation of a $50 \mathrm{MW}$ parabolic trough solar power plant with natural gas and parabolic trough solar collectors was simulated using TRNSYS software (Bakos and Parsa, [12]). The proposed power plant performance, fuel consumption and solar contribution were analyzed through six different simulation scenarios for different collector area field. Two different modes of operation, namely power boost and fuel saving, were considered. The simulation results showed that it is possible to integrate large solar fields in conventional power plants and produce viable investments.

Dayem et al. [13], using TRNSYS simulation environment, implemented a numerical simulation of the Integrated Solar Combined Power Plant. The performance results were compared with the measured data of the Kuraymat plant. The numerical results were in close agreement with the measured ones. The implemented model demonstrates the capability to perform detailed analysis and is very useful for evaluating proposed systems.

Channiwala and Ekbote [14] developed in Matlab a generalized model using the equations, correlations and typical values of parameters available in the scientific literature. The paper presents the complete details of various equations, correlations, loss models and the general data to be used by designer and outlines a systematic procedure. Channiwala and Ekbote [14] estimate the solar field size for a $25 \mathrm{~kW}$ solar-only trough plant in India. The results of the model indicate the solar field size of $245 \mathrm{~m}^{2}$ for a $25 \mathrm{~kW}$ plant.

According to Chaanaoui et al. [15] "parabolic trough collector is currently the most technically and commercially mature technology, able to yield energy either as an independent or hybrid power system with a competitive cost".

Luo et al [16] developed a modified model to do a parametric analysis of the operation of a Solar Concentration installation in order to propose a possible improvement. Several review papers have been reported in the literature focusing on experimental and numerical investigations with parabolic trough power plants around the World [17-25].

\section{TRNSYS Simulation Software}

TRNSYS is a flexible energy simulation software package due to facilitating the addition of mathematical models, the available add-on components, and the ability to interface with other 
simulation programs. From the start of TRNSYS, improvements have been made to include threedimensional geometrical building model. Engineers have been using TRNSYS extensively to simulate solar energy applications, conventional buildings, and even biological processes. The TRNSYS standard component library offers over 80 components for many different applications: HVAC, solar, hydrogen systems and many other applications. They are specifically designed to fulfill users' requirement.

TRNSYS is a software which is developed primarily at The University of Wisconsin and is a complete and extensible simulation environment for the transient simulation of systems. Models of individual components can be created and these individual models are called Types. These models of individual components are then connected within TRNSYS and simulations for the larger system run. Each Type of component is described by a mathematical model in the TRNSYS simulation engine. It is a commercially available software package and is very suited for modeling complex systems, such as parabolic trough power plants. Thermal Energy System Specialists (TESS), a TRNSYS library, contains over 500 components in 14 different Libraries. Solar Thermal Electric Components (STEC) is a TRNSYS library developed by DLR (German Aerospace Centre) and Sandia National Laboratory. STEC consists of models suitable for Rankine and Brayton cycles, concentrating solar thermal systems (central receiver, heliostat field, and parabolic trough models), and thermal storage.

\section{The Simulation}

The objective of the parabolic trough plant is to generate electricity. The parabolic trough solar power plant design considered consists in a solar field of parabolic-trough collectors, with a thermally stratified storage field linked to a Rankine cycle via a series of heat exchangers. The hydraulic circuit is constituted by two circulating pumps and respective connecting piping. Meteorological data is modeled with typical meteorological years (TMY2) generated by the Meteonorm database. The Meteonorm has a very extensive database of meteorological data collected from a worldwide network of weather stations and allows the simulation of meteorological data for specific geographical locations. The database presents a yearly average root mean square relative error of $5.4 \%$ in solar direct irradiance and a $1.4{ }^{\circ} \mathrm{C}$ in ambient temperature [26]. The simulations conducted in the present work were performed on locations where there is Meteonorm data available from a local weather station in Brazil.

The parabolic trough collector (PTC) based on the model of Lippke [1], uses an integrated efficiency equation to account for the different fluid temperature at the field inlet and outlet of the collector field. It calculates the demanded mass flow rate of the heat transfer fluid to achieve a user-defined outlet temperature.

Figure 1 shows schematic for Rankine Cycle and Fig. 2 shows the work model of a solar thermal power plant system using Parabolic Trough Collector (Type 398 - STEC Library). The program was built using compounds and models from TRNSYS and STEC/TESS library. Both the HP turbine and LP turbine consists of several components linked together, so the macro component was used for simplicity and better aid the understanding of the general view of the model. The main input parameters of Parabolic Trough Solar Plant used for the simulation are given in Tab. 1. 
Table 1: Main input data of the 30 MW Parabolic Trough Solar Plant simulation

\begin{tabular}{|l|l|l|}
\hline Parameter & Input & Unit \\
\hline $\begin{array}{l}\text { Parabolic Trough Collector Field - PTC } \\
\text { Focal axis N-S horizontal and E-W tracking } \\
\text { Generic data based on commercial market }\end{array}$ & & \\
\hline A loss coeff. & & \\
\hline B loss coeff. & 73.6 & - \\
\hline C loss coeff. & -0.0042 & - \\
\hline Cw loss coeff. & 7.40 & - \\
\hline D loss coeff. & 0 & - \\
\hline Clean reflectivity & -0.096 & - \\
\hline Length of Solar Collector - SCA & 0.94 & - \\
\hline Aperture With of SCA & 47 & $\mathrm{~m}$ \\
\hline Focal length of SCA & 5 & $\mathrm{~m}$ \\
\hline Row Spacing & 0.5 & $\mathrm{~m}$ \\
\hline Total field Area & 15 & $\mathrm{~m}$ \\
\hline Pump Max. Power & 182000 & $\mathrm{~m}$ \\
\hline Pump Max Flowrate & 1600 & $\mathrm{~kW}$ \\
\hline Demanded Outlet Temperature & 396.4 & $\mathrm{~kg} / \mathrm{s}$ \\
\hline Inlet Temperature Solar Field & 390.56 & ${ }^{\circ} \mathrm{C}$ \\
\hline Cleanliness Solar Field & 297.78 & ${ }^{\circ} \mathrm{C}$ \\
\hline Tracking mode: & 0.95 & - \\
\hline Stratified Thermal Storage Tank & & \\
\hline Volume: & 287 & \\
\hline Heat exchanger type: Shell and tube & & \\
\hline
\end{tabular}

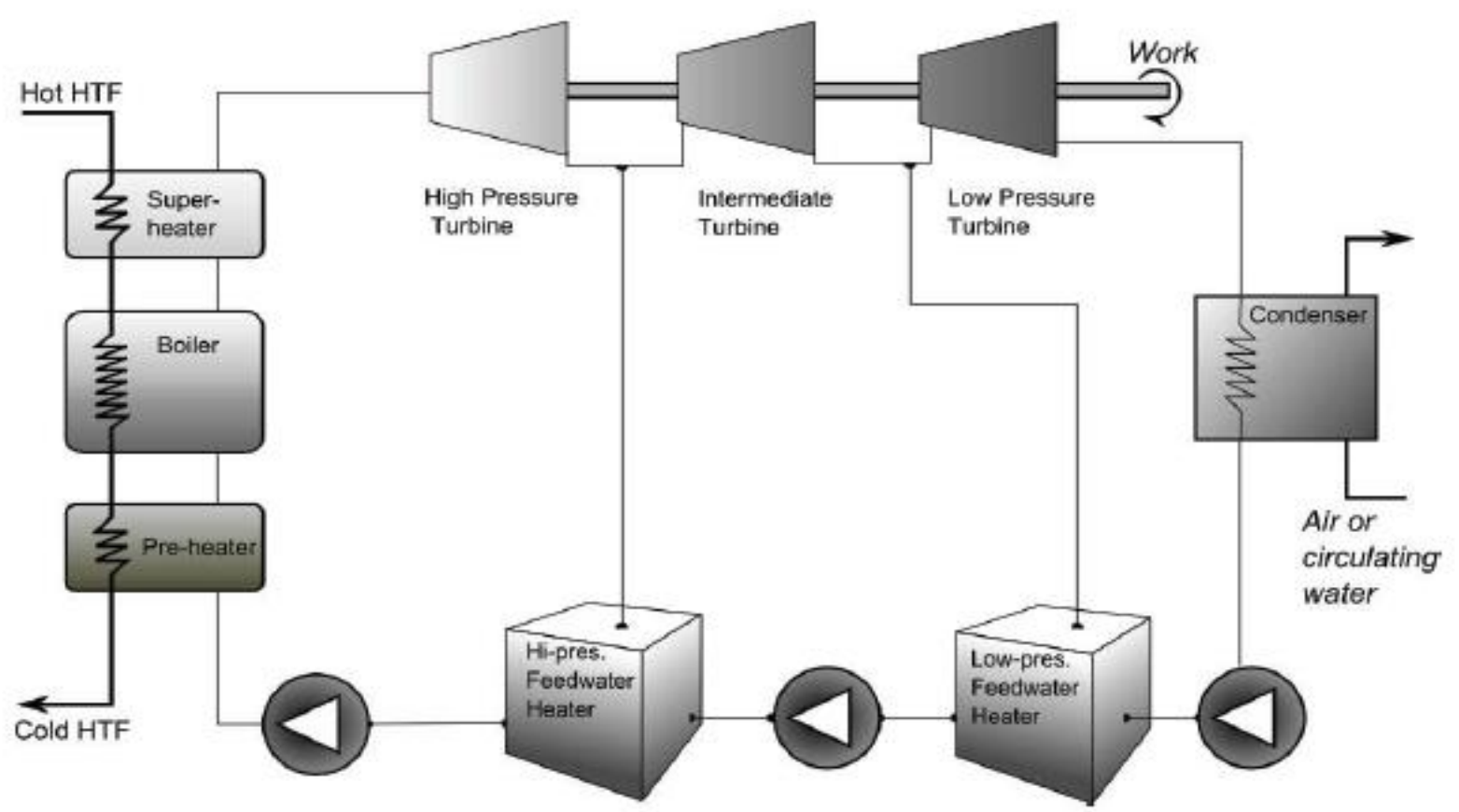

Figure 1: Schematic for simplified basis Rankine cycle (Wagner and Gilman, [27] 
A traditional Rankine cycle is used as the power cycle in these solar electric generating systems. The power cycle is driven by heat transfer from the heat transfer fluid (HTF). The HTF (Therminol VP1 is considered in this work) is heated as it circulates through the receiver and returns to the power cycle by a storage tank. The average temperature and the total volume of the HTF change significantly throughout the day. The stratified thermal storage tank accommodates these effects. The HTF is pumped from the stratified thermal storage tank and delivered to two heat exchanger systems. One of the heat exchanger systems consists of a superheater, steam generator and preheater and the other heat exchanger system is the reheater. The thermal performance of a fluidfilled sensible energy storage tank, subject to thermal stratification, was modeled by assuming that the tank consists of $\mathrm{N}(<=100)$ fully-mixed equal volume segments. The degree of stratification is determined by the value of $\mathrm{N}$. If $\mathrm{N}$ is equal to 1 , the storage tank is modeled as a fully-mixed tank and no stratification effects are possible. This turbine stage model calculates the inlet pressure of the turbine stage from the outlet pressure, the steam mass flow rate and reference values of inlet and outlet pressure and mass flow rate. It evaluates the outlet enthalpy from the inlet enthalpy and inlet and outlet pressure using an isentropic. In the simulation there are two turbines: 1) high pressure turbine (HP turbine) and 2) low pressure turbine (LP turbine). The feedwater heater increases the steam temperature and thereby reduces the heat addition from the collector loop and increases the system efficiency.

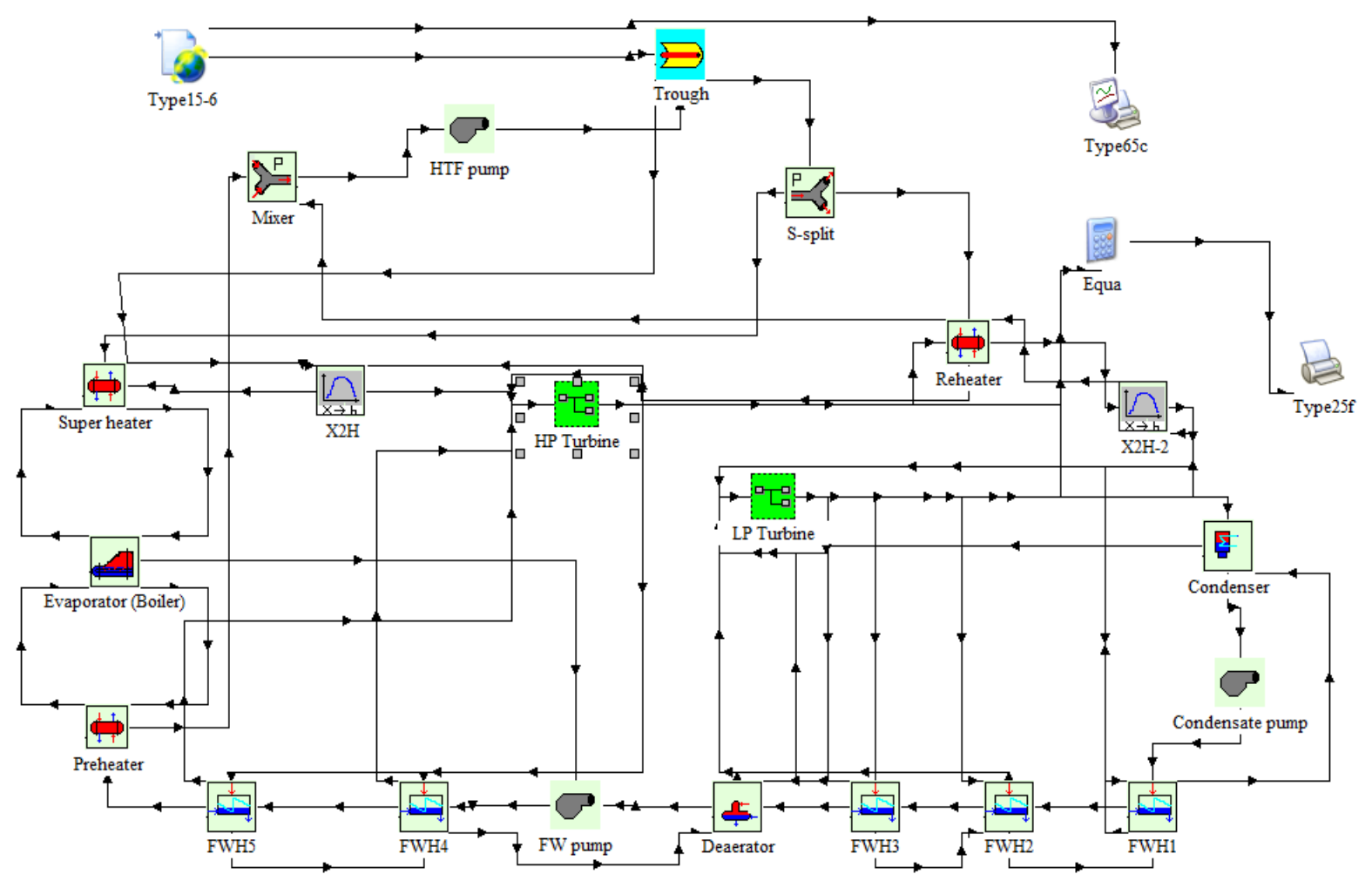

Figure 2: Simplified flow diagram of the Parabolic Trough Solar Plant

The main considerations adopted for the simulations were the following: a) The Rankine power cycle was modeled assuming all components were adiabatic and operating at steady states; b) The equations are based on mass and energy balances over each fluid stream through each component in the plant; c) There were negligible changes in potential and kinetic energy of fluid streams; d) It was assumed that all the steam generated provides useful work through the turbine; e) It was 
assumed that negligible changes in the fluid state between the outlet of one component and the inlet of the next are assumed; f) Heat exchangers are modeled using an effectiveness-NTU approach; g) The heat exchanger sizes and isentropic efficiencies were determined as a function of mass flow rate stream; h) The turbine stages were modeled in terms of isentropic efficiencies; i) The pumps were modeled in terms of isentropic efficiencies.

\section{Simulation Results}

After building up the program, the program simulation was run over a range of one year. The annual total power and annual total solar resource by site in Brazil were recorded from the weather data of 31 places in Brazil and the results are shown in Fig. 3.

Fig. 3 allow determine the different possibilities of use solar radiation in Brazil. The cities of Recife (PE), Fortaleza (CE), Belterra (PA), Salvador (BA) and Petrolina (PE) stand out for their high monthly values of direct normal irradiation (DNI) and, resulting the highest production of energy by the same configuration of Solar Central Power. In these places the Parabolic Trough Solar Power Plants, may constitute an interesting alternative to the power supply in daytime periods, mainly to support the distribution of these networks, in which the increased use of electrical energy for human comfort is changing the profile of the electricity demand.

This result is related to the highest solar resource and the number of hours when the solar radiation permits the positive heat gain in solar collector field and positive energy production. The data from Tab. 2 shows that Recife (PE) - latitude $08^{\circ} 03^{\prime} 14^{\prime \prime}$ South and longitude $34^{\circ} 52^{\prime} 51^{\prime \prime}$ West, with annual radiation level of $6264 \mathrm{MJ} /(\mathrm{hm} 2)$ has 2612 effective hours of production energy.

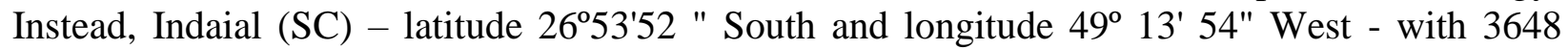
$\mathrm{MJ} /(\mathrm{hm} 2)$ has only 1245 effective hours of production energy.

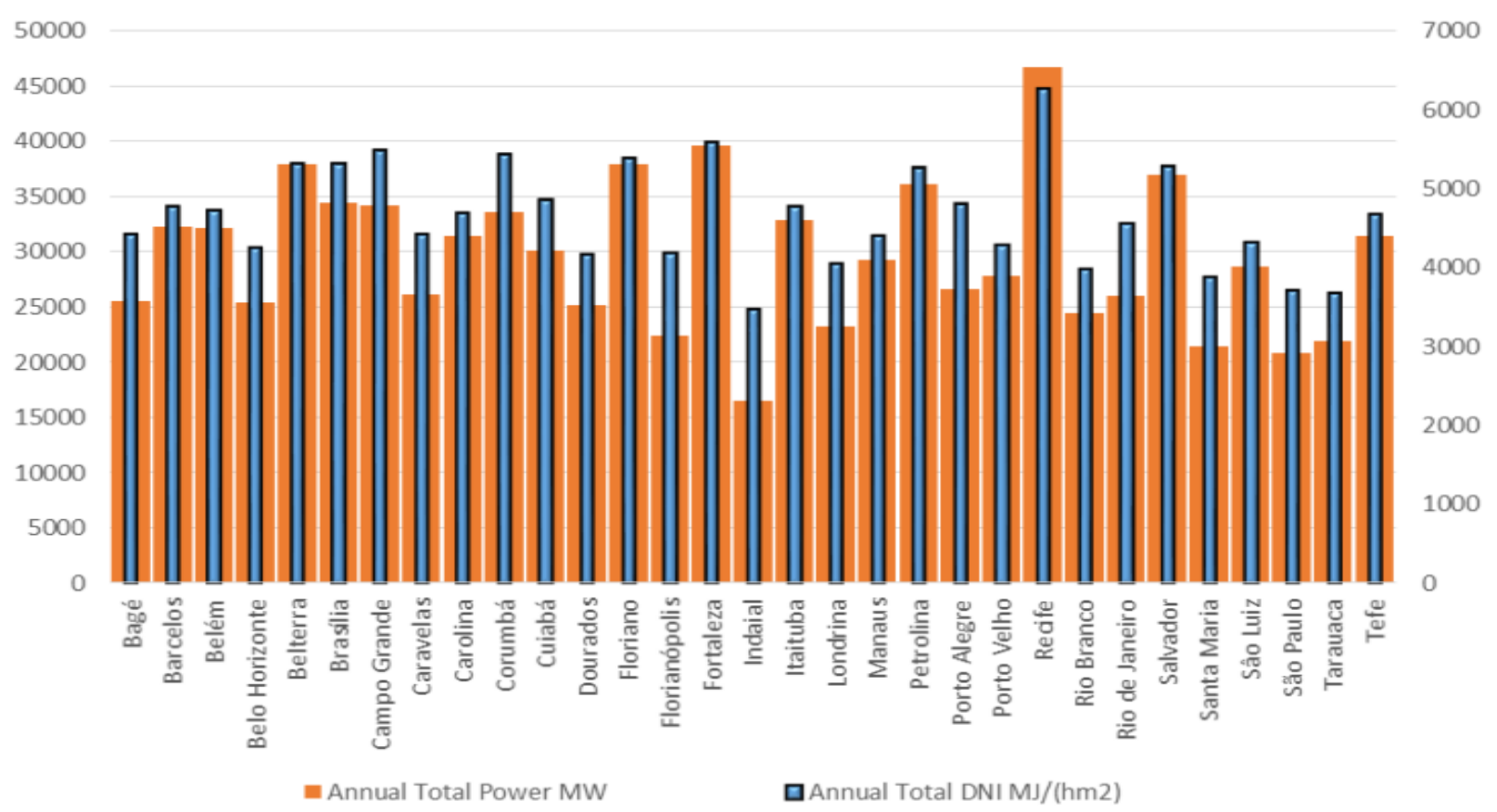

Figure 3: Annual total power and annual total solar resource by site location in Brazil 
Table 2: Comparison of number of hours of effective energy production

\begin{tabular}{|l|c|}
\hline Location/City Supply & No. of hours of effective energy production \\
\hline Recife & 2612 \\
\hline Fortaleza & 2437 \\
\hline Corumbá & 2374 \\
\hline Floriano & 2328 \\
\hline Belterra & 2257 \\
\hline Petrolina & 2212 \\
\hline Salvador & 2187 \\
\hline Florianópolis & 1491 \\
\hline Londrina & 1470 \\
\hline Santa Maria & 1416 \\
\hline São Paulo & 1356 \\
\hline Indaial & 1245 \\
\hline
\end{tabular}

Source: Authors.

It is clear that the variation of ambient temperature and beam radiation to surface affect the power generated from the turbine. The temperature of the cold side fluid entering the superheater is affected by the hot side temperature of the fluid coming from the Parabolic Trough Collector and enters the superheater. Thus, as the temperature of the fluid entering from superheater from the Parabolic Trough Collector vary due to weather changes, the cold side fluid temperature varies. Consequently, the cold side fluid entering the turbine with variation in temperature with respect to time causes the power generated from the HP turbines and LP turbines to vary with respect to time.

For this specific location, Recife, it is observed that the Parabolic Trough Solar Power Plant will remain always operational due to higher solar radiation level during the year. The Parabolic Trough Solar Power Plant is able to perform highly in conditions where there are a hot and clear days. A large difference in power can be obtained for extreme weather change. It is clear that in hot and clear summer days the average temperature is high and so is the power generated from the turbine. For instance, the maximum average power reached from the simulation in a month where there are hot and clear summer days can reach 26596.6 MW in December.

It is seen that the solar resource at collector field is relatively higher in the month of October, November, December, January, February, March and April. During these months at Recife, the sun's altitude is such that the cosine effect is quite less resulting in higher collector heat gain. The rainfall exceeds $2000 \mathrm{~mm}$ per year in Recife, concentrated between May and September (higher monthly averages $300 \mathrm{~mm}$ ), and in July the month of highest rainfall $(388 \mathrm{~mm})$. Then, due to cloud covers and the cosine effect is the highest in these months of the year, the collector heat gain will be lower. In the month of June compared to December, the decrease in solar radiation is $52 \%$ and the reduction in the heat gain of both collector fields is $65 \%$ resulting in a decrease in the solar power plant output by $73 \%$.

\section{Conclusions}

In this work, a model for the solar field and power cycle was created in the TRNSYS simulation environment using the Solar Thermal Electric Component (STEC) model library and Thermal 
Energy System Specialists (TESS). A model for a $30 \mathrm{MW}$ parabolic trough solar power plant system was developed for 31 different locations in Brazil. The system consists of a parabolic trough solar collector loop connected to a power block by a series of heat exchangers. The solar collector loop consists of a field of parabolic trough collectors, stratified thermal storage tank, pump and heat exchangers to drive the power block and uses Therminol VP1 as heat transfer fluid. The results show that the cities of Recife (PE), Fortaleza (CE), Belterra (PA), Salvador (BA) and Petrolina (PE) stand out for their high monthly values of direct normal irradiation (DNI) and, resulting the highest production of energy by the same configuration of Solar Central Power Plant. The annual results of the simulation show that, considering the errors associated with climate data, the best options for solar plants installation in Brazil are located in the cities of the Northeast region of the country. Regardless of this fact, the results show that the production of energy in the $30 \mathrm{MW}$ parabolic trough solar power plant system could represent a possibility of diversification of sustainable energy sources. Finally, it is important to note that this work can contribute and encourage other future studies about Parabolic Trough Solar Power Plants, as well as promoting incentives and public initiatives related to solar energy in Brazil.

\section{Acknowledgements}

The authors thank the support of the Universidade Federal de Viçosa (UFV). This study was financed in part by the Coordenação de Aperfeiçoamento de Pessoal de Nível Superior - Brasil (CAPES) - Finance Code 001.

\section{References}

[1] Lippke, F. (1995). Simulation of the Part-Load Behaviour of a 30 MWe SEGS Plant. Report No. SAND95-1293, SNL, Alburquerque, NM, USA.

[2] Jones, S.A., Pitz-Paal, R., Schwarzboezl, P., Blair, N. and Cable, R. (2001). TRNSYS Modeling of the SEGS VI Parabolic Trough Solar Electric Generating System, in Solar engineering 2001: proceedings of the International Solar Energy Conference: a part of FORUM 2001: Solar energy: the power to choose: April 21-25, 2001, Washington. American Society of Mechanical Engineers, 2001, p. 405.

[3] Stuetzle T. (2002). Automatic Control of the 30 MWe SEGS VI Parabolic Trough Plant. Master of Science Thesis. University of Wisconsin-Madison.

[4] Forristall R. (2003). Heat Transfer Analysis and Modeling of a Parabolic Trough Solar Receiver Implemented in Engineering Equation Solver. National Renewable Energy Laboratory NREL/TP550-34169.

[5] Patnode, A. (2006). Simulation and Performance Evaluation of Parabolic Trough Solar Power Plants. Master of Science Thesis. University of Wisconsin-Madison.

[6] Qu, M. (2014). Model Based Design and Performance Analysis of Solar Absorption Cooling and Heating System. Thesis. School of Architecture, Carnegie Mellon University. Pittsburgh, Pennsylvania (USA).

[7] Azizian, K., Yaghoubi, M. and Kenray, A. (2002). Design Experiences of the First Solar Parabolic Thermal Power Plant for Various Regions in Iran, Iranian Journal of Energy, Vol. 6, No. 12.

[8] Azizian, K., Yaghoubi, M. andKenray, A. (2011). Design analysis for expansion of Shiraz solar power plant to $500 \mathrm{~kW}$ power generation capacity, Proceedings of World Renewable Energy congress, Linkoping, Sweden, May 2011.

[9] Padilla, R.V. (2013). Simplified Methodology for Designing Parabolic Trough Solar Power Plants, Thesis. University of South Florida. 
[10] Desai, N.B., Bandyopadhyaya, S., Nayaka, J.K. Banerjeea, R. Kedare, S.B. (2013). Simulation of 1MWe Solar Thermal Power Plant. 2013 ISES Solar World Congress. Energy Procedia, Volume 57, 2014, Pages 507-516.

[11] Uçkun. C. (2013). Modeling and simulations of direct steam generation in concentrating solar power plants using parabolic trough collectors. Thesis. The Graduate School of Natural and Applied Science. Middle East Technical University.

[12] Bakos, G.C. Parsa, D. (2013). Technoeconomic assessment of an integrated solar combined cycle power plant in Greece using line-focus parabolic trough collectors. Renewable Energy 60 (2013) 598-603.

[13] Dayem, A.M.A., Metwallya, M.M., Alghamdi A.S. and Marzoukb, E.M. (2014). Numerical Simulation and Experimental Validation of Integrated Solar Combined Power Plant Energy Procedia 50 (2014) 290 - 305.

[14] Channiwala S.A. and Ekbote A. (2015). A Generalized Model to Estimate Field Size for SolarOnly Parabolic Trough Plant. SASEC2015 Third Southern African Solar Energy Conference. 11 13 May 2015. Kruger National Park, South Africa.

[15] Chaanaoui, M., Vaudreuil, S., Bounahmidi, T. (2016). Benchmark of Concentrating Solar Power Plants: Historical, Current and Future Technical and Economic Development, Procedia Computer Science, Volume 83, Pages 782-789, ISSN 1877-0509, https://doi.org/10.1016/j.procs.2016.04.167.

[16] Luo, N., Yu, G., Hou, H. J., Yang, Y. P. (2015). Dynamic Modeling and Simulation of Parabolic Trough Solar System, Energy Procedia, Volume 69, Pages 1344-1348, ISSN 1876-6102, https://doi.org/10.1016/j.egypro.2015.03.137.

[17] Messai, A., Benkedda, Y., Bouaichaoui, S., Benzerga, M. (2013). Feasibility Study of Parabolic Trough Solar Power Plant under Algerian Climate, Energy Procedia, Volume 42, Pages 73-82, ISSN 1876-6102, https://doi.org/10.1016/j.egypro.2013.11.007.

[18] Casella, F., Casati, E., Colonna, P. (2014). Optimal Operation of Solar Tower Plants with Thermal Storage for System Design, IFAC Proceedings Volumes, Volume 47, Issue 3, Pages 4972-4978, ISSN 1474-6670, ISBN 9783902823625, https://doi.org/10.3182/20140824-6-ZA-1003.02622.

[19] Al-Maliki, W. A. K., Alobaid, F., Kez, V., Epple, B., (2016). Modelling and dynamic simulation of a parabolic trough power plant, Journal of Process Control, Volume 39, Pages 123-138, ISSN 0959-1524, https://doi.org/10.1016/j.jprocont.2016.01.002.

[20] Rohani, S., Fluri, T. P., Dinter, F., Nitz, P., (2017). Modelling and simulation of parabolic trough plants based on real operating data, Solar Energy, Volume 158, Pages 845-860, ISSN 0038-092X, https://doi.org/10.1016/j.solener.2017.10.023.

[21] Praveen, R. P., Baseer, M. A. Awan, A. B., and Zubair, M. (2018). Performance Analysis and Optimization of a Parabolic Trough Solar Power Plant in the Middle East Region, Energies, 11(4), 741; https://doi.org/10.3390/en11040741.

[22] Mohammad, S. T., Al-Kayiem, H. H., Assadi, M. K., Sabir, O., Khlief, A. K. (2018). An integrated program of a stand-alone parabolic trough solar thermal power plant: Code description and test, Case Studies in Thermal Engineering, Volume 12, Pages 26-37, ISSN 2214-157X, https://doi.org/10.1016/j.csite.2018.02.006.

[23] Benramdane, M., Abboudi, S., Ghernaout, M. (2019). Contribution to the simulation and parametric analysis of the operation of a solar concentration thermal installation. International Journal of Heat and Technology, Vol. 37, No. 2, pp. 446-456. https://doi.org/10.18280/ijht.370210.

[24] Wang, A., Han, X., Liu, M., Yan, J., Liu, J. (2019). Thermodynamic and economic analyses of a parabolic trough concentrating solar power plant under off-design conditions, Applied Thermal Engineering, Volume 156, Pages 340-350, ISSN 1359-4311, https://doi.org/10.1016/j.applthermaleng.2019.04.062.

[25] Aqachmar, Z., Allouhi, A., Jamil, A., Gagouch, B., Kousksou, T. (2019). Parabolic trough solar thermal power plant Noor I in Morocco, Energy, Volume 178, Pages 572-584, ISSN 0360-5442, https://doi.org/10.1016/j.energy.2019.04.160. 
[26] Remund, J. (2008). Quality of Meteonorm Version 6.0. Proceedings of 10th World Renewable Energy Conference, Glasgow UK.

[27] Wagner, M., Gilman, P. (2011). Technical Manual for the SAM Physical Trough Model. NREL/TP-550-51825.

*Corresponding author.

E-mail address: antonio.siqueira@ ufv.br 